\author{
Olga Dąbrowska-Cendrowska \\ Uniwersytet Jana Kochanowskiego w Kielcach \\ ORCID: 0000-0002-7527-3789
}

Katarzyna Gajlewicz-Korab

Uniwersytet Warszawski

ORCID: 0000-0002-4900-2854

\title{
COVID-19 in Polish Women's Press. Preliminary research
}

\begin{abstract}
Women's press has been analysed as an element of the Polish media system by representatives of various fields of research. There have been studies of press content, formal features of individual magazines, ownership and definition issues, and internal segmentations, amongst others. This research attempts to fill a gap in the study of women's press content; it aims to show how the COVID-19 was presented in women's press. As an introduction to the main research, this article examines a carefully selected study sample with individual sub-segments of women's press each represented by a leading magazine. Research objectives include determining the ways in which COVID-19 is presented in certain women's press titles belonging to different sub-segments, analysing the selection and presentation of information to potential readers in regards to their needs, and establishing the functions of COVID-19 guidance in women's press.
\end{abstract}

Keywords: women's press, COVID-19, press guidance, celebrities.

\section{COVID-19 w prasie kobiecej w Polsce. Wstęp do badań}

\section{Streszczenie}

Prasa kobieca, jako składnik polskiego systemu medialnego, była analizowana przez reprezentantów różnych dyscyplin naukowych. Badano między innymi: jej zawartość tematyczną, cechy formalne poszczególnych magazynów, kwestie własnościowe, problemy definicyjne, wewnętrzną subsegmentację itd. Przedstawione $\mathrm{w}$ artykule badania stanowią próbę uzupełnienia luki w analizach zawartości prasy kobiecej. Celem głównym jest próba odpowiedzi na pytanie, w jaki sposób COVID-19 prezentowano w prasie kobiecej. Artykuł stanowi ustęp do badań. Próbę dobrano celowo. Poszczególne subsegmenty prasy kobiecej reprezentuje jeden wiodący tytuł. Cele szczegółowe to: sposoby prezentowania COVID-19 w poszczególnych tytułach prasy kobiecej należących do różnych subsegentów; dobór i prezentacja informacji w odniesieniu do potrzeb potencjalnych odbiorców; funkcje poradnictwa o COVID-19 w prasie kobiecej.

Słowa kluczowe: prasa kobieca, COVID-19, poradnictwo prasoue, celebryci. 


\section{Introduction}

COVID-19 is a novel infectious disease caused by the coronavirus SARS-CoV-2. It is primarily transmitted between people through respiratory droplets and contact routes $^{1}$. On $11^{\text {th }}$ January 2020, China - after examining pathogenic nucleic acids reported 41 cases of pneumonia caused by the new coronavirus ${ }^{2}$. On $30^{\text {th }}$ January 2020, The World Health Organisation (WHO) placed the novel coronavirus on the list of diseases which pose a threat to public health on a global scale ${ }^{3}$. Subsequently, on $11^{\text {th }}$ March 2020, WHO declared the outbreak of COVID-19 a pandemic.

The first case of COVID-19 in Poland was recorded on $4^{\text {th }}$ March 2020. A special law was passed on $2^{\text {nd }}$ March 2020 for preventing, counteracting and combating COVID-19, other infectious diseases and emergencies caused by them. This came into force on $8^{\text {th }}$ March 2020, and saw the implementation of specific provisions in support of the fight against COVID-19 and its consequences ${ }^{4}$. On $13^{\text {th }}$ March, the Polish Minister of Health declared a state of epidemic emergency which took effect a day later. The introduction of these legal acts enabled the application of various restrictions and requirements in many spheres of life, including economic activity 5 .

The coronavirus caused immense challenges and threats to public health - both physical and psychological - and very quickly became the centre of global attention. Information and discussion regarding COVID-19 dominated media discourse in press, radio, television, and online, particularly across social media.

Christian Fuchs supports the work of David Harvey, arguing that the coronavirus has spread worldwide in a short period of time largely due to the global network of contemporary society. Harvey refers to globalisation, which has had such an enormous impact on mobility that it has been difficult to restrict this process quickly and effectively 6 . The consequences are the worlduide pandemic and infodemic.

The pandemic brought about many changes in social life, mainly due to the forced adjustment of interpersonal relationships to new circumstances. The phrase 'social

\footnotetext{
${ }^{1}$ Ch. Fuchs, Everyday Life and Everyday Communication in Coronavirus Capitalism, „Communication, Capitalism \& Critique” 2020, No. 18, p. 376.

${ }^{2}$ Y. Zhao, S. Cheng, X. Yu, H. Xu, Chinese Public's Attention to the COVID-19 Epidemic on Social Media: Observational Descriptive Study, „Journal of Medical Internet Research” 2020, Vol. 22, No. 5, pp. 1-13.

${ }^{3}$ World Health Organization. 2020 Jan 31. Novel Coronavirus (2019-nCoV) Situation Report - 11 URL: https://www.who.int/docs/default-source/coronaviruse/situation-reports/20200131-sitrep-11-ncov.pdf?sfvrsn=de7c0f7_4 (accessed: 12.03.2021).

${ }_{4}^{4}$ Dz. U. 2020, poz. 374 [in:] http://isap.sejm.gov.pl/isap.nsf/download.xsp/WDU20200000374/T/ D20200374L.pdf (accessed: 12.03.2021).

${ }^{5}$ Dz. U. 2020, poz. 433, 441 [in:] http://isap.sejm.gov.pl/isap.nsf/dounload.xsp/WDU20200000433/ O/D20200433.pdf (accessed: 12.03.2021).

${ }^{6}$ D. Harvey, Anti-Capitalist Politics in the Time of COVID-19, Jacobin, 20 March 2020, https:// jacobinmag.com/2020/03/david-harvey-coronavirus-political-economy-disruptions (accessed: 12.03.2021).
} 
distancing' entered common parlance; indicating the introduction of mediated communication, rather than the avoidance of all communication, as Fuchs highlights?

As mentioned earlier, the topic of COVID-19 has been widely discussed in the media, which became the primary source of information about the pandemic. The subject has also been raised in women's press - which is an important part of every media system. Analysis of the available literature shows that studies on the ways in which COVID-19 is presented in women's magazines have not yet been undertaken. Researchers focus on the history and formal features of individual magazines ${ }^{8}$, internal segmentations ${ }^{9}$, ownership-related issues ${ }^{10}$, defining women's press, typology ${ }^{11}$ and the impact of new information and communication technologies on the range of press available on the market ${ }^{12}$. The thematic content of women's magazines, influenced by social reality, is also an active area of research ${ }^{13}$. Undoubtedly, the COVID-19 pandemic is a stark new social reality.

${ }^{7}$ Ch. Fuchs, Everyday Life and Everyday Communication..., p. 377.

${ }^{8}$ Z. Sokól, Prasa kobieca w Polsce w latach 1945-1995, Wydaunictwo Wyższej Szkoły Pedagogicznej, Rzeszów 1995; K. Gajlewicz-Korab, Francuska prasa drukowana. Narodziny, rozwój, era cyfrowa, Oficyna Wydawnicza Aspra-JR,, Warszawa 2018, pp. 171-175, 201-205. ${ }^{9}$ See i.a.: E. Zierkiewicz, Prasa kobieca versus pisma feministyczne. Między „dobrowolnym” zniewoleniem a „wymuszona” emancypacją? [in:] Kobiety w kulturze popularnej, eds. E. Zierkieuicz, I. Kowalczyk, Wydawnictuo Konsola, Wrocław 2002; O. Dąbrouska-Cendrouska, W stronę sprofilowanego odbiorcy mediów, „Rocznik Bibliologiczno-Prasoznawczy” 2012, No. 15, pp. 71-86; O. Dąbrouska-Cendrouska, The most important women's magazines and their publishers on the Polish press market in the year 1989-2019, „Media Biznes Kultura” 2019, No. 1 , s. 43-54.

${ }^{10}$ See i.a.: O. Dąbrouska-Cendrouska, Press offer of concerns with foreign capital on the Polish printing media market. Diagnosis after 25 years of publishing [in:] Społeczne $i$ historyczne konteksty funkcjonowania mediów, Wyższa Szkoła Humanitas, eds. M. Kaczmarczyk, D. Rott, M. Boczkouska, M. Koszembar-Wiklik, Sosnowiec-Praga 2015, pp. 121-134; M. Adamik-Szysiak, Grupa Bauer Media w Polsce. Działalność i kierunek rozwoju [in:] Inwestycje koncernów na polskim rynku medialnym. Wybrane zagadnienia, ed. L. Pokrzycka, Wydawnictwo Uniwersytetu Marii Curie-Skłodouskiej, Lublin 2012, pp. 51-96.

11 A.-O. Irimescu, Women's Magazines. Editorial Practices nad Cultural Recommendations, „Journal of Media Research” 2015, No. 8, pp. 41-53; M.I. Menèndez, Tipologia de la prensa femenina. Una propuesta de clacificatión, „Estudios sobre de Mensaje Periodistico” 2013, No. 1, pp. 191-206; R. Filas, Polskie czasopisma w XXI wieku - rozwój czy kryzys, „Zeszyty Prasoznawcze" 2007, No. 1-2, pp. 7-41; F. Candotto, La stampa al femminile [in:] Analisi e gestione della comunicazione, ed. A. Tafuri, EUT Edizioni Università di Trieste,Trieste 2010, pp. 5-31.

${ }^{12}$ C. Royal, Introducing Women to the Internet: Digital Discourse in Women's Magazines, „Southwestern Mass Communication Journal” 2008, No. 24, pp. 15-29; B. Ytre-Arne, I Want to Hold It in my Hands: Readers' Experiences of the Phenomenological Differences between Women's Magazines Online and in Print, „Media, Culture \& Society” 2011, No. 33, pp. 467-477; J. Zarem, All Digital Magazines: New Opportunity or Last Hurrah? „Folio Magazine” 2009, No. 3, pp. 12-19.

${ }^{13}$ See i.a.: K. Wodniak, Wspótczesna prasa kobieca a sprawy książki, Wydaunictuo SBP, Warszawa 2004; E. Zierkiewcz, Prasa jako medium edukacyjne. Kulturowe reprezentacje raka piersi w czasopismach kobiecych, Oficyna Wydawnicza Impuls, Kraków 2013; M. Dajnowicz, „Zwierciadło” - platforma polityczna Ligi Kobiet w okresie PRL (1957-1961, 1982-1987), „Rocznik Historii Prasy Polskiej” 2017, No. 3, pp. 67-90; Ch. Reynolds, S. LoRusso, The Women's 
Accordingly, the coronavirus theme appearing in Polish women's press in 2020 became the subject of this study. Danièle Bussy-Génevois notes that the study of women's press enables access to information about the history of civilization, traditions, customs and everyday life ${ }^{14}$. Women's magazines featuring content related to the coronavirus accompany women in their everyday lives, helping them deal with the side effects of the pandemic which go beyond the remit of clinical and laboratory medicine. Therefore, this study attempts to answer the following questions: How was information about COVID-19 presented in individual women's magazines across different subsegments? Was the selection and presentation of content determined by the needs of potential readers? ${ }^{15}$

The research hypothesis holds that the way in which the pandemic is presented does reflect the needs of readers of individual magazine titles. Women in Poland have differing preferences and expect different content from the press: some groups prefer purely informative materials, others advice or real stories based on the lives of other women. Polish women's magazines have responded to this demand.

\section{What is women's press?}

Encyklopedia wiedzy o prasie (Encyclopaedia of Press Studies) defines women's press as 'a group of magazines, mainly weeklies, whose profiles are shaped according to the reading needs and social position of women. Therefore, aside from journalistic articles, reportages, feuilletons, literary work, and also in some magazines, even general press releases (political and other) - their content consists mainly of sections and columns devoted to fashion, household, parenting and family matters ${ }^{\prime 16}$. Further, we read: 'an important quality of Polish women's press is its persistent drive to enhance knowledge (especially practical) and the cultural level of women, in addition to constant improvement in the engagement and position of women in social and professional life ${ }^{\prime 17}$.

Magazines Diet: Frames and Sources in Nutrition and Fitness Articles, „Journal of Magazines and New Media Research" 2016, No. 1, pp. 4-21; O. Dąbrouska-Cendrouska, Guidance in Mass Media - Analysis of the Selected Examples, „Respectus Philologicus” 2018, No. 33, pp. 17-26; U. Ćwik, Zagadnienie praw kobiet na łamach „Kobiety i Zycie” (1970-1989), „Czasopismo Naukowe Instytutu Studiów Kobiecych” 2016, No. 1, pp. 66-83; E. Roche, C. Sécail. La presse magazine comme objet de recherche [in:] Manuel d'analyse de la presse magazine, ed. C. Blandin, Armand Colin, Paris 2018, pp. 31-49.

${ }_{14}$ D. Bussy-Gènevios, Aproximación metodológica a la prensa paramujeres en España (1931-1936) [in:] La prensa de los siglos XIX y XX. Metodología, ideología e información. Aspectos económicos y tecnológicos: I Encuentro de la Historia de la Prensa, eds. C. Garitaonandia Garnacho, M. Tuñón de Lara, Universidad del País Vasco/Euskal Herriko Unibertsitatea, Servicio de Publicaciones, Bilbao 1996.

${ }_{15}$ This is an introduction to the study, determining the coverage of the research field.

${ }^{16}$ Encyklopedia wiedzy o prasie, ed. J. Maślanka, Ossolineum, Kraków 1976, p. 172. The author of the English translation of dictionary and encyclopaedia entries is Kinga Mrozouska.

${ }^{17}$ Ibidem. 
Since the emergence of this definition, the situation of women's press has changed significantly, and not only in Poland ${ }^{18}$. The ever-increasing popularity of online media, and consequent disruption to the print media business model, led the publishers of women's magazines to also distribute prepared content via women's internet services. Returning to the definition of women's press, it should be noted that an individual entry does not appear in Stownik terminologii medialnej (Dictionary of Media Terminology). A reference to women's press, however, appears under the definition of a magazine: [[...] magazines focus particularly on providing entertainment. Aside from general magazines which are on a decline, there are a growing number of magazines for children (educational), young people (youth culture) ${ }^{19}$, women (mainly advice - fashion, beauty, health, household), and men (hobby - DIY, fishing, erotica, motoring) ${ }^{20}$.

Women's press researcher Joke Hermes, referring to this type of magazine definition, states that women's press is read predominantly for pleasure, 'to kill time'21. Women who took part in her study explained that they reach for women's press when they have nothing to do, or when they are performing a task - usually related to household management - which does not require their full attention ${ }^{22}$. The clear reference to leisure time suggests that female readers are used to reading women's magazines as utilitarian guides. Hermes aptly states that 'the repertoire of practical knowledge legitimizes them as a group of professional magazines for housewives [...] recipes, advice on stain removal or opening tightly closed jars are shown as handy and valuable. These activities are presented as if they were the only everyday tasks ${ }^{23}$. The ideal reader of women's press is a pragmatic, practical woman, well-versed in solving current issues in everyday life.

It was mentioned in the introduction that women's press is an important and broad press segment in the Polish media market. Although the range of magazine titles available reveals the diversity of this segment, researchers have tried to create consistent and thorough typologies. Zofia Sokół divides Polish women's press into three groups:

- Bottom of the range - magazines addressed to a mass audience; to women who are less educated, come from small towns and are less well-off. These are usually

\footnotetext{
${ }_{18}$ More on online women's magazines see: K. Kavita, S.P. Chang, X. Wenjing, Online Women's Magazines: Differences in Perceptions between Print and Online Magazines among Female Readers, „Advances in Journalism and Communication” 2016, No. 4, pp. 31-42; A. Walker Ruff, The Relationship of Women's Magazines and Their Websites: A Comparative Analysis of Print and WebContent. Theses and Dissertations, 2012 [in:] http://scholarworks.uark.edu/ etd/546 (accessed: 12.11.2019).

${ }_{19}$ With the development of new information and communication technologies the magazine segment aimed at young people systematically diminishes. The bi-weekly magazine 'Bravo' a leader in this press sector - was closed in 2018. 'Bravo Sport' and 'TubeNews' were popular amongst readers.

${ }^{20}$ Stownik terminologii medialnej, ed. W. Pisarek, TAiWPN Universitas,, Kraków 2006, p. 114.

${ }^{21}$ J. Hermes, Reading Women's Magazines. An Analysis of Everyday Media Use, Polity Press,

Cambridge 1995, p. 34.

${ }^{22}$ Ibidem, p. 35.

${ }^{23}$ Ibidem, p. 36.
} 
weekly and bi-weekly advice and gossip magazines such as 'Naj', 'Tina', 'Pani Domu';

- Mid-range - intended for women from medium-sized towns with a higher income, better educated, often professionally active and trying to combine work and private life. This group consist of monthly magazines e.g. 'Claudia', 'Poradnik Domouy', 'Śuiat Kobiety';

- Top of the range - their readers are women who are ambitious, come from big cities, are professionally active, pursue a successful career, and juggle roles of mother, employee and wife ${ }^{24}$.

\section{Research methodology}

This study contains both systematic and content analyses. In addition, elements of a case study approach ${ }^{25}$ are used in relation to description of the specifics of Polish women's press and the pandemic in Poland. Content analysis is used to objectively, systematically and quantitatively describe the apparent content of communication ${ }^{26}$. The conducted analysis is both qualitative and quantitative ${ }^{27}$. After outlining research questions, the aims of the study were defined and a hypothesis was put forward regarding the impact of the COVID-19 pandemic on determining topics in women's press depending on the potential addressee/reader/audience. Subsequently, a coding frame was developed based on the criteria proposed by Walery Pisarek and Bernard Berelson $^{28}$.

High-circulation women's magazines form a broad sector of the press market which belongs almost entirely to foreign publishers. Therefore, a systematic analysis was used to select three titles. Whilst undertaking preliminary (pilot) studies to confirm or negate the advisability of further analyses of COVID-19-related content in the press, the body of research was determined. Using the divisions of women's press proposed by Sokól, three magazines were selected, each representing one of the suggested groups $^{29}$. The criterion for selection was the best position in terms of copy sales in 2018. At the time of writing, these were the latest complete figures published by ZKDP

${ }^{24}$ Z. Sokól, Prasa kobieca $w$ Polsce..., pp. 16-17. Compare with the typologies proposed by D. Zaworska-Nikoniuk, Wzory kobiecości $w$ prasie dla kobiet w XXI w., Wydaunictuo Adam Marszałek, Toruń 2008, p. 56; E. Zierkiewicz, Prasa kobieca versus..., pp. 31-50; R. Filas, Polskie czasopisma w XXI wieku..., pp. 46-48; O. Dąbrouska-Cendrouska, Zmieniająca się rzeczywistość polskiej prasy kobiecej w (1989-2019), Wydawnictwo Uniwersytetu Jana Kochanouskiego, Kielce 2020, pp. 17-21.

${ }_{25}$ R.K. Yin, Case Study Research. Design and Methods, Sage Publications Inc, Los Angeles 2017, p. 16.

${ }^{26}$ B. Berelson, Content analysis in Communication Research, Free Press, Glencoe 1952, p. 18.

${ }^{27}$ Due to formal reasons, the article presents the results of the quantitative analysis. The results of the qualitative analysis of the five given features will be presented in subsequent articles.

${ }^{28}$ W. Pisarek, Analiza zawartości prasy, Ośrodek Badań Prasoznawczych RSW „Prasa-Książka-Ruch", Kraków 1983, p. 103.

${ }^{29}$ Further in the text the term 'subsegment' will be used. 
(Zwiazek Kontroli Dystrybucji Prasy/Press Distribution Control Association). The three groups are represented by Bauer Media's 'Przyjaciółka' (bottom-range), 'Kobieta i Życie' (mid-range) and 'Tuój Styl' (top-range). These represent general magazines that offer a broad spectrum of topics which aim to interest women. The study time frame is made up of two specific dates: $30^{\text {th }}$ January 2020, when WHO declared a global public health emergency due to the spread of the COVID-19 epidemic ${ }^{30}$, and $21^{\text {st }}$ December $2020-$ when the European Commission approved two vaccines for the European market, taking a new step in the fight against the pandemic ${ }^{31}$. It is important to emphasise that this is also a full publishing year for each magazine. The study sample contains a total of 48 issues of the three magazines (12 'Twój Styl' - monthly; 12 'Kobiety i Życie' monthly; 24 'Przyjaciółka' - biweekly). The material collected was analysed in terms of five categories: publishing frequency, theme, narrative, 'subjects' and type of content.

\section{Results}

The results of the analysis indicate that regardless of the publishing frequency of a title, the number of pieces regarding COVID-19 is similar. Materials taken into account contain at least one of the below keywords:

- pandemic;

- COVID-19;

- coronavirus;

- SARS-CoV-2.

'Twój Styl' published the highest number of materials (38), followed by 'Przyjaciółka' (31), and the monthly magazine 'Kobieta i Styl' (26). The frequency of COVID-19 related texts appearing each month seems interesting: taking into account the entire study sample, in the period from May to August 2020, there were a minimum of two such articles published per month.

Table 1. The number of COVID-19 related publications in 2020

\begin{tabular}{|l|c|c|c|c|c|c|c|c|c|c|c|c|c|}
\hline Magazine & I & II & III & IV & V & VI & VII & VIII & IX & X & XI & XII & Total \\
\hline Kobieta i Życie & 0 & 0 & 0 & 0 & 2 & 5 & 4 & 2 & 4 & 3 & 5 & 1 & 26 \\
\hline Twój Styl & 0 & 0 & 0 & 0 & 5 & 13 & 7 & 4 & 3 & 2 & 3 & 1 & 38 \\
\hline Przyjaciółka & 0 & 0 & 1 & 1 & 11 & 5 & 4 & 1 & 0 & 2 & 4 & 2 & 31 \\
\hline
\end{tabular}

Source: own research.

Fear associated with the lack of knowledge about the virus and its spread, as well as the consequences of lockdown, contributed to a hunger for information which was satisfied by the magazines chosen for this analysis. We find that in March, only ${ }^{30} \mathrm{WHO}$ publishes interactive timeline of its response, https://www.who.int/emergencies/ diseases/novel-coronavirus-2019/events-as-they-happen, (accessed: 12.03.2021).

${ }^{31}$ European Commission authorizes first safe and effective vaccine against COVID-19, https:// ec.europa.eu/commission/presscorner/detail/en/ip_20_2466, (accessed: 12.03.2021). 
the editorial office of 'Przyjaciółka' responded to this demand and published one article over its two issues. The greatest number of texts were published by 'Twój Styl' in June, when there were as many as 13 pieces directly or indirectly related to the pandemic or the virus. This number is undoubtedly influenced by the volume of the journal, as the aforementioned monthly magazine has the most pages of all the titles analysed, and its articles contain the most characters. In order to illustrate the dynamics of change in the publication of COVID-19 related materials, the data gathered is shown on the chart below.

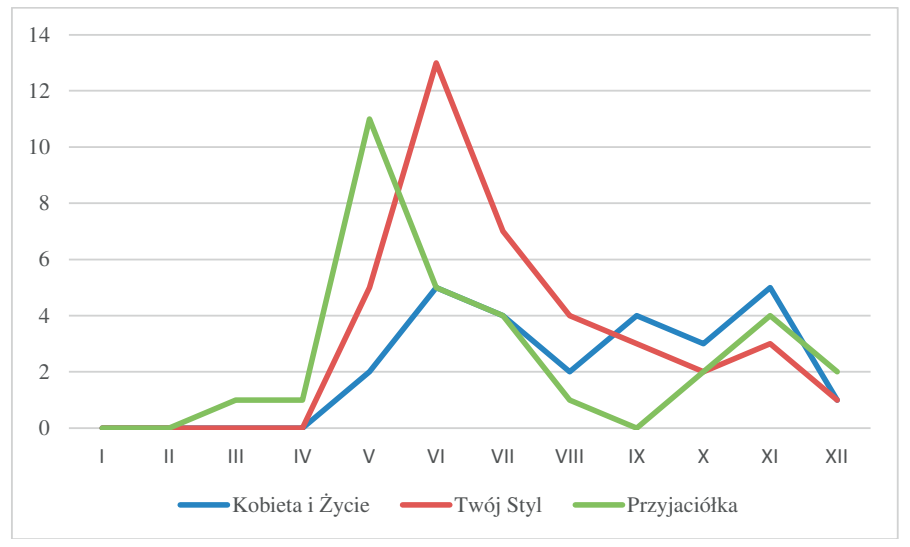

Chart 1. Dynamics of COVID-19 related publications

Source: own research.

Subject matter was the next feature under analysis. The research material taken in its entirety shows that the leading theme in the context of the pandemic was clearly health, with interpersonal relationships and work just behind. This does not appear surprising, as apart from the medical repercussions of the virus, society struggled with self-isolation regulations and the ensuing issues of job losses and remote working. Self-isolation also drew people's attention towards problems in interpersonal relationships resulting from being in the same space every day. Work, education and leisure were all confined to the proverbial 'four walls'. The forced intensification of family contact, combined with forced isolation from public life became a source of conflict for some, and a cause of self-reflection for others. The latter was addressed by actors, who shared their impressions during the first month of lockdown. The state of being 'locked-down', previously seen only on TV shows like 'Big Brother', created new problems which had been absent in these types of magazines thus far.

It is also worth looking at thematic diversity in individual titles. Interpersonal relationships were the most frequent theme of COVID-related articles in 'Twój Styl', mostly presented from the perspective of celebrities and also experts. 'Kobieta i Życie' focused equally on health and interpersonal relationships, while in 'Przyjaciółka' over $50 \%$ of the relevant material was dedicated to health issues. Some magazine titles 
quite often addressed other topics too, which indicates that the analysed magazines try to differentiate their content depending on the target audience. For example, in the monthly magazine 'Kobieta i Życie' over 16\% of materials referred to leisure time during the pandemic, and 'Twój Styl' (known for its focus on culture) covered this topic in $12 \%$ of its COVID-related content. Highly educated readers - such as the target demographic of 'Twój Styl' - seem to be interested in science and seek more ambitious content. Accordingly, this topic appears only in the aforementioned magazine (6\%). Overall, in regards to subject matter, there were no major differences between the magazines analysed from different subsegments. Chart 2 illustrates the themes of studied materials.

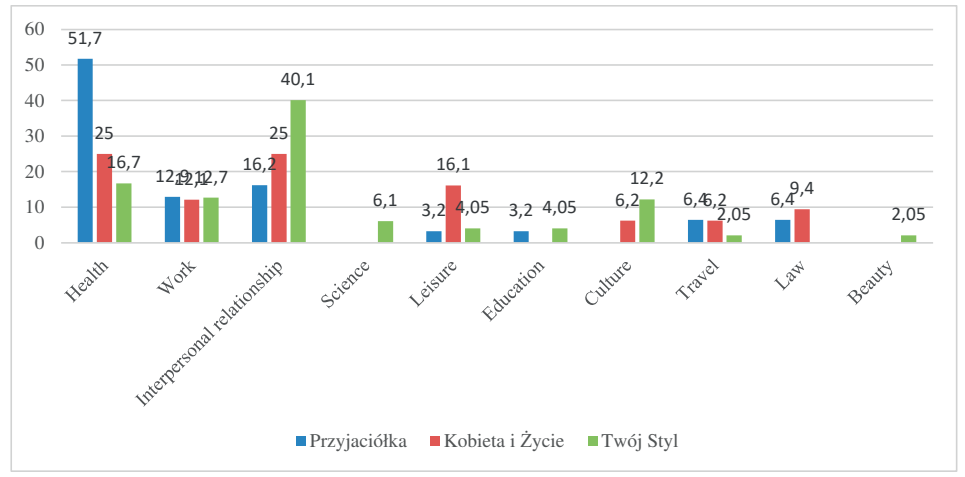

Chart 2. Themes of COVID-related articles in women's press [\%]

Source: own research.

The tone of the researched materials was the most prominent feature revealing differences between women's magazines in the context of the COVID-19 pandemic. Interestingly, the tone of 'Przyjaciółka' follows an obviously different trend to that of 'Tuój Styl' and 'Kobieta i Życie'. As many as 74\% of this magazine's publications present the subject in a neutral, purely informative way, and only 16\% of materials have positive content. Therefore, it can be inferred that 'Przyjaciółka' attempted to educate its readers, satisfying their hunger for information rather than offering comfort and drawing an optimistic picture of the world.

Both 'Twój Styl' and 'Kobieta i Życie' aimed to depict the surrounding reality in a positive light, focusing on subject material like intervieus and reportages which fostered hope. The positive content from these two magazines includes intervieus with celebrities who shared their methods for enduring the pandemic. They pointed to the possibility of pausing; using this time to reflect on your life and decisions. They assured readers that with the right attitude towards lockdown, you can become reacquainted with yourself, your thoughts, desires and needs. In their pieces, celebrities encouraged people to care for one another, and pay attention to those in need. A negative tone can be discerned most often in 'Kobieta i Życie', though it represents just 15\% of all 
COVID-related content in this magazine, and appears in materials predominantly concerned with complications after illness and the psychological consequences of prolonged lockdown. Chart no. 3 presents the different types of tone found in the analysed content.

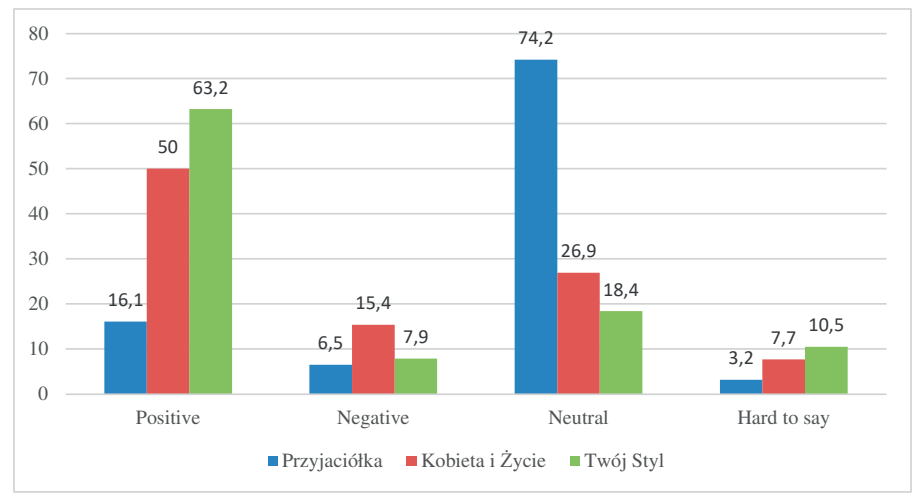

Chart 3. Tone of the analysed content [\%]

Source: own research.

Considering the type of content as a variable, it should be noted that articles not characterized by any specific genre-related features prevailed. An emphasis on informative articles can be seen in 'Przyjaciółka' (64\%), 'Kobieta i Życie' (30,8\%), and 'Twój Styl' (21\%). In particular, content from 'Przyjaciółka' and 'Kobieta i Życie' can be classed as typical articles with guidance features. This confirms the hypothesis that women from lower social backgrounds looked for information about the pandemic in the women's press.

Expert advice during the pandemic, often present in 'Przyjaciółka' and 'Kobieta i Życie', also seems to have educational value. However, it should be emphasised that this advice appeared not in the form of complex guidance, but as a couple of sentences of information. The qualitative analysis of this feature will be the subject of another article. Additionally, it is worth noting that expert opinions in 'Twój Styl' were presented differently from the other two magazines.

Remarkably, no intervieus regarding COVID-19 have appeared in 'Przyjaciółka'. Intervieus (mainly with 'ordinary people') are characteristic of the other two magazines, whereas the bi-weekly 'Przyjaciółka' does not share in this tradition and did not deviate from its standard editorial policy during the pandemic. Chart 4 presents the data discussed. 


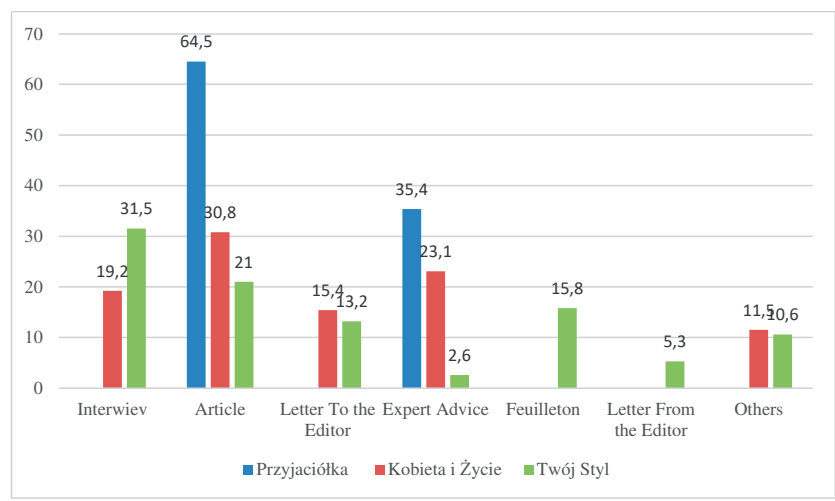

Chart 4. Types of content used to present COVID [\%]

Source: own research.

As mentioned, the vast majority of 'subjects' (people whom the content is about) belonged to the category of 'ordinary people'. This was apparent foremost in 'Przyjaciółka' (almost 97\%) and 'Twój Styl' (52,7\%). 'Tuój Styl' and 'Kobieta i Życie' featured the most diverse range of 'subjects', highlighting social diversity, while 'Przyjaciółka' focused on the lives of 'ordinary people' in its pandemic-related articles.

Additionally, it is important to examine the role of health professionals, who appeared in all three of the analysed magazines during the COVID-19 pandemic. All three also place a spotlight on senior citizens - for whom the pandemic has been particularly challenging - with editors encouraging sensitivity towards older people's needs. It is worth highlighting that a greater diversity of 'subjects' is most characteristic of 'Twój Styl' (with its more demanding readers) which perceives the 'subject' as an example from a specific socio-occupational group. Chart 5 presents the relevant data.

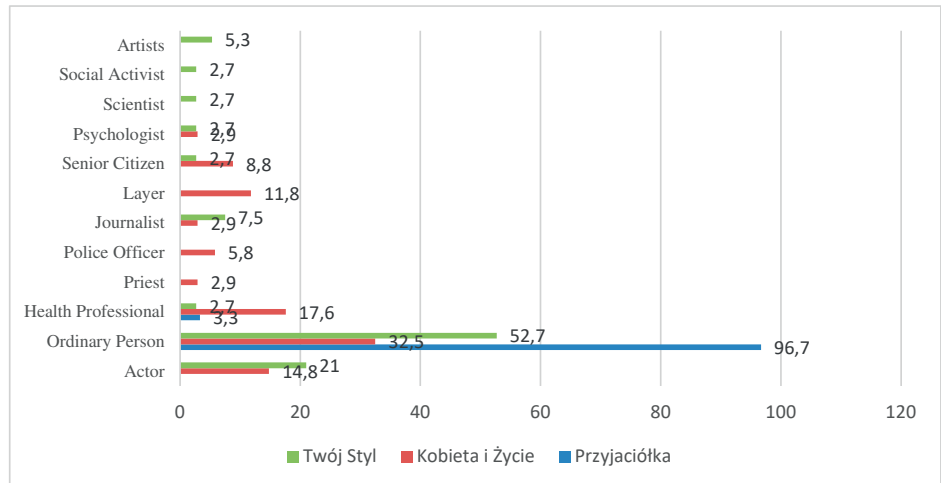

Chart 5. Press content 'subjects' [\%]

Source: own research. 


\section{Summary}

Women's press is an important element of the Polish media system. The variety of press available allows adult female readers, regardless of their age, education, finances, or other socio-demographic and psycho-social features, to find the magazine that suits their needs.

Women's magazines have always adjusted their content to current events and society, adapting to their readers' interests. They deal with issues within the spectrum of interests of a well-profiled potential female reader. Therefore, in 2020, women's magazines could not omit the topic of COVID-19. The distribution of published content was varied, both in terms of the month of release, as well as the press subsegment to which the title under study belonged. Editorial work on individual issues happens in advance, which explains the fact that in the first quarter the analysed magazines did not publish COVID-related content. During that time, the main source of current information was television and the internet.

From May 2020, the COVID-19 pandemic has been a fixture in women's press. Magazine content concerned mainly health, interpersonal relationships and work. It appears that these three spheres of life were most affected by the pandemic and the resulting lockdowns. Health seems to be particularly important to readers of women's press; magazines addressed this concern with both advice from health professionals (taking on the role of an expert) and domestic tips on how to fight the virus. The positive or neutral tone which dominated published content filled readers with optimism. Its role was to reassure and accustom them to the new social reality.

Analysis of the collected material in terms of the five selected features - i.e. frequency of publication, theme, tone, 'subjects', and type of content - confirmed the multiplicity of presentation of COVID-related information in women's press. Despite the fact that the virus concerns all social groups, each socio-demographic group looks for different content in the press. Pandemic-related articles were different in each magazine title, highlighting the variety of women's reading preferences in Poland. In the future, this research should be further extended to include qualitative analysis and analysis of groups of readers. Nevertheless, this research reveals that the presence of pandemic-related content in women's press was immensely important, as it is mainly women that are the victims of the socio-economic consequences of the pandemic. Amnesty International report, highlights that during the pandemic, the risk of job loss for women increased by as much as 44\%. Simultaneously working from home, running a household, and looking after children puts women under the most severe testing ${ }^{32}$. It is the media, and mainly the press - which Poles place great trust in - that bears responsibility for educating, informing, counselling, and even comforting and maintaining hope (e.g. by suggesting beneficial patterns of behaviour). Women's press fulfils this role for Polish women.

${ }^{22}$ Dlaczego w pandemii zostawiliśmy kobiety na lodzie? OPINIA; https://wuw.dw.com/pl/ dlaczego-w-pandemii-zostawili\%C5\%9Bmy-kobiety-na-lodzie-opinia/a-57117983, (accessed: 10.05.2021). 


\section{References}

Adamik-Szysiak M., Grupa Bauer Media w Polsce. Działalność i kierunek rozwoju [in:] Inwestycje koncernów na polskim rynku medialnym. Wybrane zagadnienia, ed. L. Pokrzycka, Wydawnictwo Uniwersytetu Marii Curie-Skłodowskiej, Lublin 2012.

Berelson B., Content analysis in Communication Research, Free Press, Glencoe 1952.

Bussy-Gènevios D., Aproximación metodológica a la prensa paramujeres en España (1931-1936) [in:] La prensa de los siglos XIX y XX. Metodología, ideología e información. Aspectos económicos y tecnológicos: I Encuentro de la Historia de la Prensa, eds. C. Garitaonandia Garnacho, M. Tuñón de Lara, Universidad del País Vasco/Euskal Herriko Unibertsitatea, Servicio de Publicaciones, Bilbao 1996.

Candotto F., La stampa al femminile [in:] Analisi e gestione della comunicazione, ed. A. Tafuri, EUT Edizioni Università di Trieste, Trieste 2010.

Ćwik U., Zagadnienie praw kobiet na łamach 'Kobiety i Życia' (1970-1989), „Czasopismo Naukowe Instytutu Studiów Kobiecych" 2016, No. 1, pp. 66-83.

Dajnowicz M., 'Zwierciadło' - platforma polityczna Ligi Kobiet w okresie PRL (1957-1961, 1982-1987), „Rocznik Historii Prasy Polskiej” 2017, No. 3, pp. 67-90.

Dąbrouska-Cendrouska O., Guidance in Mass Media - Analysis of the Selected Examples, „Respectus Philologicus” 2018, No. 33, pp. 17-26.

Dąbrouska-Cendrouska O., Press offer of concerns with foreign capital on the Polish printing media market. Diagnosis after 25 years of publishing [in:] Społeczne i historyczne konteksty funkcjonowania mediów, eds. M. Kaczmarczyk, D. Rott, M. Boczkouska, M. Koszembar-Wiklik, Wyższa Szkoła Humanitas, Sosnowiec-Praga 2015.

Dąbrouska-Cendrouska O., The most important women's magazines and their publishers on the Polish press market in the year 1989-2019, „Media Biznes Kultura” 2019, No. 1, pp. 43-54.

Dąbrouska-Cendrouska O., W stronę sprofilowanego odbiorcy mediów, „Rocznik Bibliologiczno-Prasoznawczy" 2012, No. 15, pp. 71-86.

Dąbrouska-Cendrouska O., Zmieniająca się rzeczywistość polskiej prasy kobiecej (1989-2019), Wydawnictwo Uniwersytetu Jana Kochanouskiego, Kielce 2020.

Dz. U. 2020, poz. 374, http://isap.sejm.gov.pl/isap.nsf/download.xsp/WDU20200000374/T/ D20200374L.pdf (accessed: 12.03.2021).

Dz. U. 2020, poz. 433, 441, http://isap.sejm.gov.pl/isap.nsf/dounload.xsp/WDU20200000433/O/ D20200433.pdf (accessed: 12.03.2021).

Encyklopedia wiedzy o prasie, ed. J. Maślanka, Ossolineum, Kraków 1976.

European Commission authorises first safe and effective vaccine against COVID-19, https:// ec.europa.eu/commission/presscorner/detail/en/ip_20_2466, (accessed: 12.03.2021).

Filas R., Polskie czasopisma w XXI wieku - rozwój czy kryzys, „Zeszyty Prasoznawcze” 2007, No. 1-2, pp. 7-41.

Fuchs Ch., Everyday Life and Everyday Communication in Coronavirus Capitalism, „Communication, Capitalism \& Critique" 2020, No. 18, pp. 375-399.

Gajlewicz-Korab K., Francuska prasa drukowana. Narodziny, rozwój, era cyfrowa, Oficyna Wydawnicza Aspra-JR, Warszawa 2018.

Harvey D., Anti-Capitalist Politics in the Time of COVID-19, Jacobin, 20 March 2020, https://jacobinmag.com/2020/03/david-harvey-coronavirus-political-economy-disruptions (accessed: 12.03.2021). 
Hermes J., Reading Women's Magazines. An Analysis of Everyday Media Use, Polity Press, Cambridge 1995.

Irimescu A.-O., Women's Magazines. Editorial Practices nad Cultural Recommendations, „Journal of Media Research” 2015, No. 8, pp. 41-53.

Kavita K., Chang S.P., Wenjing X., Online Women's Magazines: Differences in Perceptions between Print and Online Magazines among Female Readers, „Advances in Journalism and Communication" 2016, No. 4, pp. 31-42.

Menèndez M.I., Tipologia de la prensa femenina. Una propuesta de clacificatión, „Estudios sobre de Mensaje Periodistico" 2013, No. 1, pp. 191-206.

Pisarek W., Analiza zawartości prasy, Ośrodek Badań Prasoznawczych RSW „Prasa-Książka-Ruch", Kraków 1983.

Reynolds Ch., LoRusso S., The Women's Magazines Diet: Frames and Sources in Nutrition and Fitness Articles, „Journal of Magazines and New Media Research” 2016, No. 1, pp. 4-21.

Roche E., Sécail C., La presse magazine comme objet de recherche [in:] Manuel d'analyse de la presse magazine, ed. C. Blandin, Armand Colin, Paris 2018.

Royal C., Introducing Women to the Internet: Digital Discourse in Women's Magazines, „Southwestern Mass Communication Journal” 2008, No. 24, pp. 15-29.

Stownik terminologii medialnej, ed. W. Pisarek, TAiWPN Universitas, Kraków 2006.

Sokół Z., Prasa kobieca w Polsce w latach 1945-1995, Wydawnictwo Wyższej Szkoły Pedagogicznej, Rzeszóu 1995.

Walker Ruff A., The Relationship of Women's Magazines and Their Websites: A Comparative Analysis of Print and WebContent. Theses and Dissertations, 2012, http://scholarworks. uark.edu/etd/546 (accessed: 12.11.2019).

WHO publishes interactive timeline of its response, https:/www.who.int/emergencies/diseases/ novel-coronavirus-2019/events-as-they-happen, (accessed: 12.03.2021)

Wodniak K., Wspótczesna prasa kobieca a sprawy książki, Wydawnictwo SBP, Warszawa 2004. World Health Organization. 2020 Jan 31. Novel Coronavirus (2019-nCoV) Situation Report - 11 URL: https://www.who.int/docs/default-source/coronaviruse/situation-reports/20200131-sitrep-11-ncov.pdf?sfvrsn=de7c0f7_4 (accessed: 12.03.2021).

Yin R.K., Case Study Research. Design and Methods, Sage Publications Inc., Los Angeles 2017. Ytre-Arne B., I Want to Hold It in my Hands: Readers' Experiences of the Phenomenological Differences between Women's Magazines Online and in Print, „Media, Culture \& Society” 2011, No. 33, pp. 467-477.

Zarem J., All Digital Magazines: New Opportunity or Last Hurrah? „Folio Magazine” 2009, No. 3, pp. 12-19.

Zaworska-Nikoniuk D., Wzory kobiecości w prasie dla kobiet w XXI w., Wydawnictuo Adam Marszałek, Toruń 2008.

Zhao Y., Cheng S., Yu X., Xu H., Chinese Public's Attention to the COVID-19 Epidemic on Social Media: Observational Descriptive Study, „Journal of Medical Internet Research” 2020, Vol. 22, No. 5, pp. 1-13.

Zierkiewcz E., Prasa jako medium edukacyjne. Kulturowe reprezentacje raka piersi $w$ czasopismach kobiecych, Impuls, Kraków 2013.

Zierkiewicz E., Prasa kobieca versus pisma feministyczne. Między 'dobrowolnym' zniewoleniem a 'wymuszona' emancypację? [in:] Kobiety w kulturze popularnej, eds. E. Zierkiewicz, I. Kowalczyk, Wydawnictwo Konsola, Wrocław 2002. 